the courses will also be able to take a recognised exam.

So far 60 schools have been opened throughout the country including the wartorn North. The schools have been set up in anything from disused factories to railway carriages. The organisers are aiming for a total of 1,000 centres.

Prime Minister Premadasa asked the Inter- national School to launch the new language campaign. A spokesman for the school said: 'Our brief was quite straightforward: reach the masses and reach them within six months.'

Many of the Sri Lankan staff involved are retired English teachers who have been specially retrained. Next year a new secondlevel TV course will be launched.

\section{TDKs in China}

(extract: Helen Berg in Peking, 'China's Old Guard loses ground in the war of English words', Sunday Times, 10 Feb 91).

Goodbye, Comrade, hello Miss. Chinese may be the most common tongue on the planet, spoken by a third of the world's population, but when a young man whispers in his girlfriend's ear, English is the language to aim for. His words as well as his thoughts become ideologically unsound.

This week, on St Valentine's day, thousands of sophisticated young Chinese will delight in the Western tradition of exchanging heart-shaped 'lovers' day' cards, many with English greetings. Young women now blush with pleasure at being called 'Miss' (xiaopie) because it sound so elegant and high-brow. In the heat of passion, 'sexy girlfriend' and 'make love' are also in vogue ....

Students are doing their best to outrage. The old revolutionaries wince at the latest 'hot slang' of the eduated, urban youths who call themselves TDKs, after the cassette tape brand. The acronym stands for their three bourgeois obsessions: Toefl (test of English as a foreign language, an exam that is a passport to travel abroad), dancing and kissing.

In spite of the denunciation of such pursuits by the Peking Daily News, which demanded that students 'should not fritter away their youthful days with frivolities,' English words such as 'kiss', 'party' and 'okay' continue to win wider currency among ordinary workers.

In the park young couples coax their babies with 'bye-bye' instead of 'zai jian', while some Chinese seeking cachet without understanding shock tourists by sporting $\mathrm{T}$-shirts with sexual invitations emblazoned on their chests.

\section{Catalan}

(extract: Marlise Simons, 'Word by Word, Catalonia's Cultural Identity Takes Hold', International Herald Tribune, 20 April 91).

Perhaps most remarkable is the way the Catalans have challenged the dominance of the Spanish language, the official tongue of Spain's 36 million people and 200 million others in Latin America.

In less than 10 years, Catalonia has driven Spanish largely out of public life and made its own language a principal vehicle of official speeches, primary and secondary education and several local radio and television channels and newspapers.
It has been a huge operation, with towns nailing thousands of new street names to their walls and replacing the word calle for street with carrer.

Films and videotapes are dubbed. Signs in shops now say sortida instead of salida, for exit, and tancat not cerrado, is the sign for closed. . . .

Nationalists feel they have recently scored some important victories. They have persuaded the European Community to recognize Catalan as an official EC language, the first minority tongue to obtain this status.

And the 1992 Olympic Games, to be held in Barcelona, will have four official languages: English, French, Spanish and Catalan. 